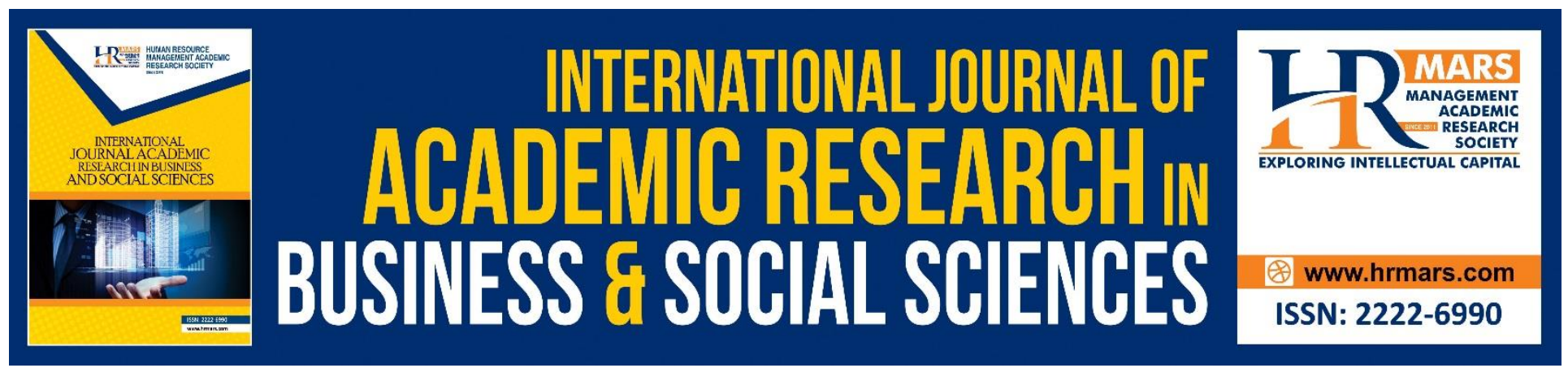

\title{
Effect of Post-Exercise Chocolate Milk Consumption on Subsequent Exercise Performance and Mood State
}

Nor Aijratul Asikin Mohamad Shalan, Nur Adilah Izzati Mohamad Shari, Norhazira Abdul Rahim and Hishamuddin Ahmad

To Link this Article: http://dx.doi.org/10.6007/IJARBSS/v9-i6/5964

DOI: 10.6007/IJARBSS/v9-i6/5964

Received: 16 April 2019, Revised: 19 May 2019, Accepted: 05 June 2019

Published Online: 25 June 2019

In-Text Citation: (Shalan, Shari, Rahim, \& Ahmad, 2019)

To Cite this Article: Shalan, N. A. A. M., Shari, N. A. I. M., Rahim, N. A., \& Ahmad, H. (2019). Effect of Post-Exercise Chocolate Milk Consumption on Subsequent Exercise Performance and Mood State. International Journal of Academic Research in Business and Social Sciences, 9(6), 451-461.

Copyright: (C) 2019 The Author(s)

Published by Human Resource Management Academic Research Society (www.hrmars.com)

This article is published under the Creative Commons Attribution (CC BY 4.0) license. Anyone may reproduce, distribute, translate and create derivative works of this article (for both commercial and non-commercial purposes), subject to full attribution to the original publication and authors. The full terms of this license may be seen at: http://creativecommons.org/licences/by/4.0/legalcode

Vol. 9, No. 6, 2019, Pg. 451 - 461

Full Terms \& Conditions of access and use can be found at http://hrmars.com/index.php/pages/detail/publication-ethics 


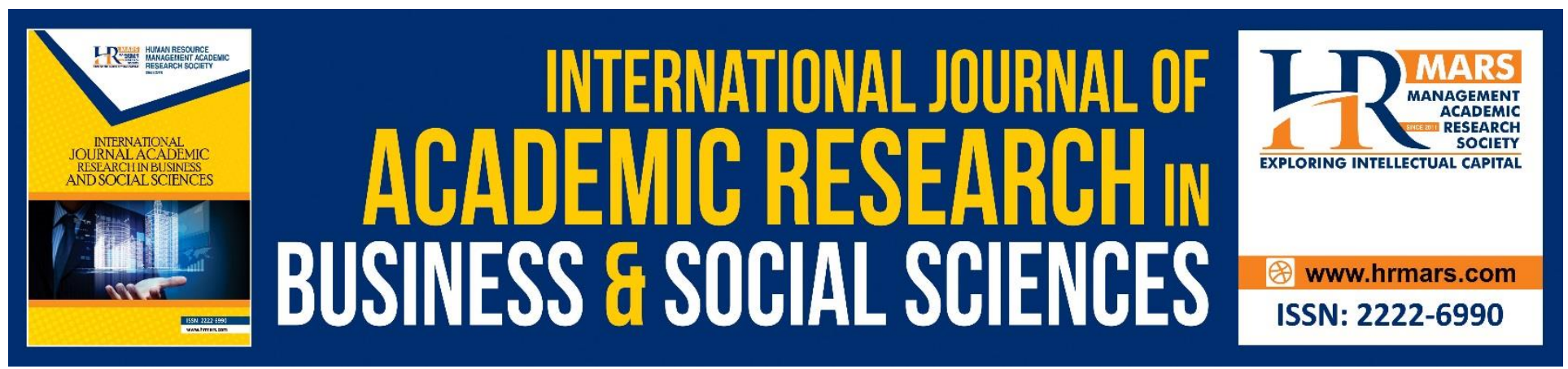

\title{
Effect of Post-Exercise Chocolate Milk Consumption on Subsequent Exercise Performance and Mood State
}

\author{
Nor Aijratul Asikin Mohamad Shalana ${ }^{*}$, Nur Adilah Izzati Mohamad \\ Sharia ${ }^{\mathrm{a}}$ Norhazira Abdul Rahim ${ }^{\mathrm{a}}$ and Hishamuddin Ahmad ${ }^{\mathrm{a}}$ \\ ${ }^{a}$ Faculty of Sport Science and Coaching, Sultan Idris Education University, Tanjung Malim, Perak, \\ Malaysia
}

\begin{abstract}
A demand for nutritional supplements to enhance recovery after endurance training is increasing among athletes to maximize their performance. The present study was conducted to identify the effects of chocolate milk consumption on blood glucose level, hydration status and mood state of the athlete after aerobic exercise. Ten male students from the Faculty of Sport Science and Coaching, UPSI (23.7 \pm .68 years) participated in two trials separated by 1 week. For each trial consumed either chocolate milk (CM) or glucose drink (GD) after a 60 minute run at $70 \%$ of VO2max $(46.43 \pm 1.32$ $\mathrm{ml} / \mathrm{kg} / \mathrm{min}$ ). Blood glucose levels were determined 1 and 2 hours after post-exercise CM or GD ingestion. Urine samples were collected before and 2 hours after exercise to assess hydration status. The mood state of the subject was also measured using the BRUMS questionnaire. The data were analysed by using a paired sample t-test. The results show that blood glucose levels and the urine colour are not significantly different between CM and GD consumption after exercise. Consumption of CM and GD able to reduce the feelings of tiredness, fatigue and depression, and increase vigour. These findings indicate both drinks can be consumed as a post-exercise recovery drink for endurance athletes.
\end{abstract}

Keyword: Chocolate Milk, Post-Exercise, Recovery, Blood Glucose, Urine Colour, Mood.

\section{Introduction}

Muscle recovery after physical activity is very significant, particularly in sports and rehabilitation. Muscle fatigue can be defined as a reduction in the ability to increase muscle strength or power regardless of whether the task is retained or is caused by the peripheral (Enika and Duchateau, 2008) or central nerves (Gandevia, 2001). Due to this matter, two important aspects need to be encountered to reduce fatigue and enhance recovery which are through peripheral mechanism consist of energy compound restoration, and central mechanism represented by stress-related brain chemical production. In specific, peripheral recovery depends on body glycogen storage (Jentjens \& Jeukendrup, 2003) and rehydration (Shirreffs, Armstrong, \& Cheuvront, 2004). Long-term 
deterioration may also be associated with muscle injury caused by exercise and muscle soreness (DOMS). In terms of recovery after endurance training, the main goal of dietary intervention is usually to promote the process of rebuilding the glycogen synthesis of the muscle and the recovery of liquids (Roy, 2008).

The addition of proteins and carbohydrates has been shown to positively affect the rebuild of glycogen synthesis and the same durability performance when supplements occur immediately or after 2 hours of training. This might as well increase protein synthesis and reduce protein degradation, which will cause further stimulation of muscle tissue repair (Ivy, 2003). According to Valentine and team, chocolate milk has a good combination of protein, electrolytes and carbohydrates for post-exercise recovery (Valentine et al., 2008). Some studies have identified that skim milk and low-fat chocolate milk have the ability to help in resynthesizing glycogen, promoting increased lean muscle mass and assist in rehydration after exercise compared to drinking mineral water and commercial beverages (Hartman et al., 2007; Karp et al., 2006; Shirreffs, Watson, \& Maughan, 2007). Dairy proteins found in liquid milk have been reported to help increase the synthesis of muscle protein and endurance (Ferguson-Stegall et al., 2011) and obstacle training as well as potentially effective in repairing muscle damage after exercise (Cockburn et al., 2008; Gilson et al., 2010; Pritchett et al., 2009). Studies also showed that the use of chocolate milk after exercise can improve the performance of subsequent endurance during repeated exercise (Ferguson-Stegall et al., 2011; Thomas, Morris, \& Stevenson, 2009) and speed up recovery during intensive football training (Gilson et al., 2010; Spaccarotell \& Andze, 2011).

As important as enhancing recovery through increasing glycogen synthesis, emotion as one of the central mechanism element also will affect total recovery after exercise, and the intake of macro and micro-nutrient also has been said to have the ability to affect mood (Benton \& Donohoe, 1999). Carbohydrate can relieve depression by triggers insulin production in the body, which will then regulate blood sugar in the cell for energy production, and simultaneously affects neurotransmitters such as serotonin in the brain (Rao et al., 2008). By containing carbohydrates and protein, chocolate milk can be hypothesized to be able to affect emotion after exercise.

Although chocolate milk has been proved as a potential drink for post-exercise recovery, there several studies showed contradict findings. Consumption of chocolate milk showed no different than other recovery beverages on ratings of perceived exertion and it is also not significantly affect time to exhaustion (Ferguson-Stegall et al., 2011; Gilson et al., 2010; Spaccarotell \& Andze, 2011). Several studies also showed that chocolate milk was not significantly affected muscle soreness, heart rate (Gilson et al., 2010), creatine kinase (Pritchett et al., 2009), lactate (Thomas et al., 2009), and glycogen content (Lunn et al., 2012). Due to these contradictions, this study has been designed to investigate the effect of chocolate milk consumption on subsequent exercise performance and mood state. 


\section{Methodology}

\section{Instrument}

Eligibility for participation in the study was determined through the maximum level of oxygen intake (VO2max). Hydration status was quantified by using the urine colour chart. Heart rate was monitored using Fitmate Pro (COSMED, Italy). Blood sugar levels were performed by glucometer. Each testing trials was conducted using a treadmill. Oxygen consumption and respiratory gas exchange were analysed using a Fitmate Pro (COSMED, Italy). The rating of perceived exertion (RPE) during the testing trials was quantified using the Cleveland 1-10 Scale. Brunel Mood Scale (BRUMS) translated into Malay language (Terry et al., 1999) were used to measure mood. The BRUMS is a 24 -item mood scale that measures 6 identifiable affective states through a self-report inventory, with respondents rating a list of adjectives on a 5-point Likert scale.

\section{Participant}

In order to recruit subjects, a group meeting with the researcher and the potential research subject was scheduled. Potential subjects were informed of the purpose, nature and details, as well as any risks associated with participation in the study during a meeting. The subject inclusion criteria included: 10 male student of Sultan Idris Education University, specific for endurance athletes, age between 23 to 25 years old, body mass index between 18 to 22 in normal phrase, athlete must be in a good health status based on health history form, subjects should have $\mathrm{VO}_{2}$ max between $45-50$ $\mathrm{ml} / \mathrm{kg} / \mathrm{min}$ and no injury or illness that would prevent the individual from completing any part of the study.

\section{Preliminary Testing}

Each subject performed an exercise test to exhaustion (treadmill running) to determine $\mathrm{VO}_{2}$ max. Constant running speed was maintained while treadmill incline (starting at $0 \%$ ) increased by $2 \%$ every 2 min. $\mathrm{VO}_{2} \max$ was defined as the oxygen consumption at which referring to the subject's heart rate, rating of perceived exertion (RPE) or the subject was unable to continue running. Running speed for exercise at $70 \%$ of $\mathrm{VO}_{2} \max$ for the final test was determined after athletes achieve the volitional fatigue.

\section{Experimental Protocol}

Participants performed an experimental protocol comprising of two treatments. These two treatments were separated by 1 week. Each treatment protocol consists of 60 minutes running on a treadmill at $70 \%$ of $\mathrm{VO}_{2}$ max followed by a 2 hour recovery period during which subjects consumed $500 \mathrm{ml}$ of each of the two experimental beverages. Both protocols were identical with the exception of the composition of the beverage consumed during recovery. Subjects randomly consumed either chocolate milk (CM) or glucose drink (GD). Blood glucose levels were determined before exercise to identify fasting glucose sugar followed by 1 and 2 hours after post-exercise consuming chocolate milk or glucose drink. Urine samples also were collected before exercise and 2 hours after exercise to assess hydration status. The participants also complete a BRUMS questionnaire to identify mood state after exercise and after consuming each drink. All baseline data is compared with the same parameter after finishing the treadmill exercise. 


\section{Recovery Period}

Participants rested in the laboratory for a 2 hour recovery period. Within 30 minutes after ending the exercise, participants were provided with a recovery drink of either chocolate milk or glucose drink. Participants completed a BRUMS questionnaire throughout the recovery period to determine their mood responses to the drink provided. A set of 24 subscales of mood questions were presented in the form of 6 factors which is anger, confused, depressed, tired, fatigue and vigour. Participants were also asked to not taking any calories food or drink throughout the recovery process. Each question required the participant to mark their current perception on a Likert Scale comprising five responses such as not at all to very much so. Blood sample and urine test were taken at the end of the recovery process.

\section{Data Analysis}

BRUMS data, urine colour chart and blood glucose levels will be analyzed descriptively and inferred. For descriptive analysis, the data obtained will be reported using mean, standard deviation and percentage. The paired t-test will be used to compare the data of all participants for the test involving chocolate milk drinks and glucose drinks. The significant level of mean difference is set at $p<0.05$. SPSS version 20 software will be used for all data analysis.

\section{Result}

\section{Participant}

The characteristics of the intended subject are based on age between 23 to 25 years old and the mean of age is $23.70 \pm .675$ years. Body mass index (BMI) which in between 18 to 22 in normal phrase and the subjects achieved the level of $\mathrm{VO}_{2} \max$ between $45-50 \mathrm{ml} / \mathrm{kg} / \mathrm{min}$. The mean of body mass index was $21.64 \pm 1.57 \mathrm{~kg} / \mathrm{m} 2.70 \%$ of $\mathrm{VO}_{2} \max$ will be used as training intensity for each subject in the laboratory test. Therefore, the selected subjects in this test should run for 60 minutes according to the rate of maximum heart rate of $\mathrm{VO}_{2}$ max respectively. The mean of $70 \% \mathrm{VO}_{2} \mathrm{max} 46.43 \pm 1.32$ $\mathrm{ml} / \mathrm{kg} / \mathrm{min}$.

\section{Blood Glucose Levels}

Figure 1 shows the blood glucose level after $1 \mathrm{~h}$ and $2 \mathrm{~h}$ post chocolate milk and glucose drink. Paired $\mathrm{t}$-test analyzed shows that blood glucose level after $1 \mathrm{~h}$ and $2 \mathrm{~h}$ consumption of both drinks were not significantly different ( $p>0.05$ ). For chocolate milk, the blood glucose level after $1 \mathrm{~h}$ was $5.60 \pm .72$ $\mathrm{mmol} / \mathrm{L}$ compared to $5.89 \pm .87 \mathrm{mmol} / \mathrm{L}$ for $2 \mathrm{~h}$ chocolate milk consumption. For glucose drink, post $1 \mathrm{~h}$ blood glucose level was $6.32 \pm 1.74 \mathrm{mmol} / \mathrm{L}$ while the $2 \mathrm{~h}$ post blood glucose level was $5.98 \pm .58$ $\mathrm{mmol} / \mathrm{L}$. 


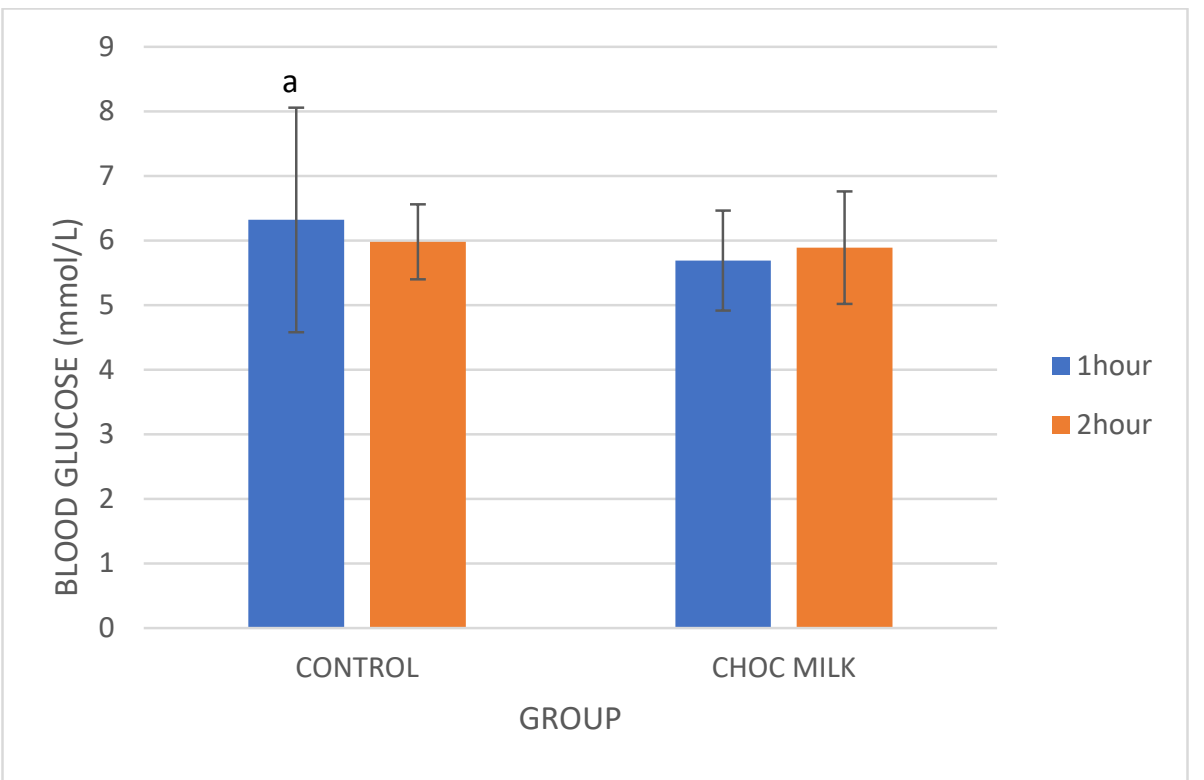

Figure 1- Blood glucose level. Values are expressed as mean $\pm S D(n=10)$. Means with different superscript letters within the same graph are significantly different $(p>0.05)$.

\section{Urine Colour}

Figure 2 shows the urine colour after $1 \mathrm{~h}$ and $2 \mathrm{~h}$ post chocolate milk and glucose drink. Paired t-test analyzed shows that urine colour after $1 \mathrm{~h}$ and $2 \mathrm{~h}$ consumption of both drink were significantly different $(p<0.05)$. For chocolate milk, the blood glucose level after $1 \mathrm{~h}$ was $5.2 \pm 1.5$ compared to 3.8 \pm .9 for $2 \mathrm{~h}$ chocolate milk consumption. For glucose drink, post $1 \mathrm{~h}$ blood glucose level was $5.8 \pm 1.40$ while the $2 \mathrm{~h}$ post blood glucose level was $3.5 \pm 1.71$.

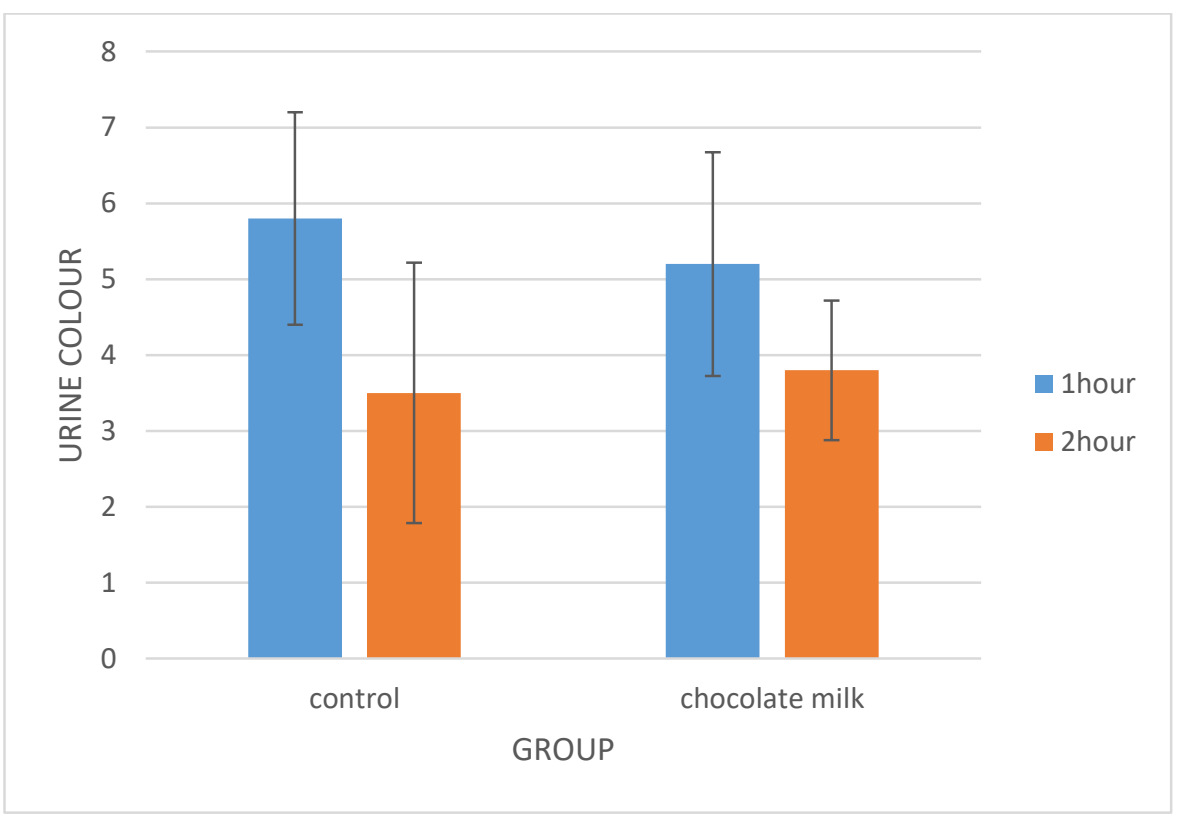

Figure 2- Urine colour. Values are expressed as mean \pm SD $(n=10)$. 
INTERNATIONAL JOURNAL OF ACADEMIC RESEARCH IN BUSINESS AND SOCIAL SCIENCES

Vol. 9, No. 6, June, 2019, E-ISSN: 2222-6990 @ 2019 HRMARS

\section{Mood State}

Table 1 shows mood state after exercise and consuming the chocolate milk. The mean mood state for anger after exercise $(1.0 \pm .00)$ is the same as mean after consuming chocolate milk (1.0 \pm .00$)$. The mean mood state for confused after exercise $(1.1 \pm .175)$ is significantly lower than mean after consuming chocolate milk (1.3 \pm .791$)$. The mean mood state for depressed after exercise (1.2 \pm .472$)$

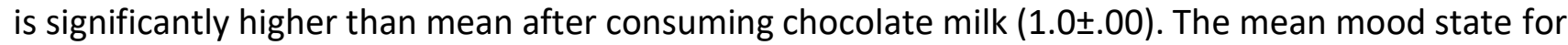
tired after exercise $(2.7 \pm .755)$ is significantly higher mean after chocolate milk (1.8 \pm .598$)$. The mean mood state for fatigue after exercise $(1.3 \pm .563)$ is significantly higher mean after consuming chocolate milk (1.0 \pm .00$)$. The mean mood state for vigour after exercise $(2.7 \pm 1.27)$ is significantly higher mean after consuming chocolate milk (3.1 \pm 1.04$)$.

Meanwhile, the mood state after exercise and consuming the glucose drink. The mean mood state for anger after exercise $(1.0 \pm .317)$ is higher than after consuming glucose drink (1.1 \pm .00$)$. The mean mood state for confused after exercise $(1.2 \pm .362)$ is significantly lower than mean after consuming glucose drink (1.0 \pm .00$)$. The mean mood state for depressed after exercise $(1.1 \pm .241)$ is significantly

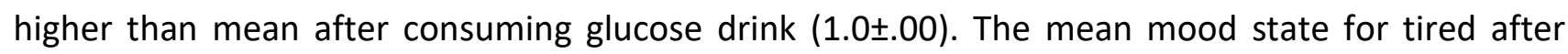
exercise $(2.5 \pm .908)$ is significantly higher mean after glucose drink (1.8 \pm .546$)$. The mean mood state for fatigue after exercise $(1.3 \pm .621)$ is significantly higher mean after consuming glucose drink $(1.0 \pm .00)$. The mean mood state for vigour after exercise $(2.5 \pm 1.057)$ is significantly lower mean after consuming glucose drink (3.2 \pm 1.124$)$.

The mood state for both drinks was assessed immediately after exercise and $2 \mathrm{~h}$ after consuming drinks. Apart from vigour and tiredness, all other mood subscales were not significantly different at both points for both of the drinks. In regards to vigour and tiredness, for chocolate milk vigour was significantly different between after exercise $(2.7 \pm 1.7)$ and $2 \mathrm{~h}$ post-exercise consumption (3.1 \pm 1.0$)$ while for glucose drink, vigour was also significantly different between after exercise $(2.5 \pm 1.0)$ and $2 \mathrm{~h}$ post-exercise consumption $(3.2 \pm 1.1)$. 
INTERNATIONAL JOURNAL OF ACADEMIC RESEARCH IN BUSINESS AND SOCIAL SCIENCES Vol. 9, No. 6, June, 2019, E-ISSN: 2222-6990 @ 2019 HRMARS

Table 1 Mood state for drink consumption.

\begin{tabular}{cccc}
\hline Mood factors & Situation & CM Mean( \pm SD $)$ & $\begin{array}{c}\text { GD } \\
\text { Mean }( \pm S D)\end{array}$ \\
\hline Anger & After exercise & $1.0 \pm .00$ & $1.1 \pm .32$ \\
& 2h post drink & $1.0 \pm .00$ & $1.0 \pm .00$ \\
Confusion & After exercise & $1.1 \pm .17$ & $1.2 \pm .36$ \\
& 2h post drink & $1.3 \pm .79$ & $1.0 \pm .00$ \\
Depression & After exercise & $1.2 \pm .47$ & $1.1 \pm .24$ \\
& 2h post drink & $1.0 \pm .00$ & $1.0 \pm .00$ \\
Tiredness & After exercise & $2.7 \pm .75$ & $2.5 \pm .91$ \\
& 2h post drink & $1.8 \pm .59$ & $1.8 \pm .55$ \\
Fatigue & After exercise & $1.3 \pm .56$ & $1.3 \pm .62$ \\
& 2h post drink & $1.0 \pm .00$ & $1.0 \pm .08$ \\
Vigour & After exercise & $2.7 \pm 1.3$ & $2.5 \pm 1.0$ \\
& 2h post drink & $3.1 \pm 1.0$ & $3.2 \pm 1.1$ \\
\hline
\end{tabular}

Values are expressed as mean \pm SD $(n=10)$. CM, chocolate milk; $G M$, glucose drink.

\section{Discussion}

The purpose of this study was to identify the effects of chocolate milk consumption on blood glucose level, hydration status and mood state of the athlete after aerobic exercise. Chocolate milk has been suggested to be an effective recovery drink because of its nutritional composition, and it is further appealing because it is relatively inexpensive and readily available (Karp et al. 2006). Some recent investigations have reported that the combination of carbohydrate (CHO) and Protein (PRO) during heavy endurance exercise may improve subsequent exercise performance versus taking $\mathrm{CHO}$ only (Saunders et al. 2004). However, a number of studies have reported no differences in subsequent performance between $\mathrm{CHO}$ and $\mathrm{CHO}+$ PRO recovery beverages (Luden et al. 2007).

This study found that the blood glucose levels post $1 \mathrm{~h}$ and post $2 \mathrm{~h}$ consumption of chocolate milk (CHO+PRO) and glucose, were not significantly different significant between the two-time points and between the different drinks. Blood glucose levels $2 \mathrm{~h}$ post chocolate milk consumption remained high compared to glucose drink. This would suggest that chocolate milk is better in maintaining blood glucose levels compared to glucose drinks which suffered a drop of $6.3 \%$ from the initial value. Previous studies have reported glycogen synthesis occurs most quickly when a large amount of carbohydrates are immediately consumed and at 15-60 minute intervals thereafter, for up to 5 hours after exercise (Jentjens \& Jeukendrup, 2003).

Result of blood glucose level after $2 \mathrm{~h}$ consuming chocolate milk is maintained compared to glucose drink which only works effectively at the first hour of the recovery process. Hence, the chocolate milk is suitable if another exercise session is scheduled after the recovery period. Previous study found increment in subsequent muscle function (Skillen et al. 2008; Valentine et al. 2008) and cycling 
INTERNATIONAL JOURNAL OF ACADEMIC RESEARCH IN BUSINESS AND SOCIAL SCIENCES Vol. 9, No. 6, June, 2019, E-ISSN: 2222-6990 @ 2019 HRMARS

performance (Thomas et al. 2009; Valentine et al. 2008) and reduced fatigue (Skillen et al. 2008) with consumption of $\mathrm{CHO}+$ PRO compared to $\mathrm{CHO}$ only. A study conducted by Thomas et al. (2009) showed a longer time to exhaustion in the subsequent exercise bout by participants consumed CM than other comparison beverage, hence support the potential of $\mathrm{CM}$ as a post-exercise recovery beverage.

Another purpose of the study was to identify the hydration status after exercise where urine colour was determined from urine samples collected immediately after and after 2 hours after exercise. The results show that chocolate milk and glucose consumption after exercise were effective in restoring body fluid after exercise. This was determined from the urine colour changes between immediately after exercise and $2 \mathrm{~h}$ after exercise. Shirreffs, Watson, \& Maughan, (2007) found that low-fat milk is effective in restoring the balance of the lost fluid after exercise. Carlton \& Orr (2015) discussed the idea of losing body fluids in the form of dehydration, damaging the athlete's physical performance is not a new thing. Sweat caused by dehydration that can have an adverse effect on physiological function and subsequent exercise performance (Cheuvront et al. 2003; Coyle, 2004) and after exercise restoration of fluid balance can help reduce it.

Examining the impact of exercise on fatigue, anger, vigour, depression, and confusion, as measured by the BRUMS questionnaire, the finding showed significant increase especially in tired and vigour. Interestingly, after consumed chocolate milk and glucose drink, the scales on tiredness, fatigue and depression decreased, increased the scale of vigour, but no changes on anger, confusion. There are many suggestions that macro and micro-nutrient intake can affect mood (Benton \& Donohoe, 1999). Carbohydrate consumption increased serotonin release thus elevating mood and reduce the feeling of depression (Wurtman \& Wurtman, 1995).

\section{Conclusion}

The aim of this study is to determine the ability of chocolate milk in enhancing post-exercise recovery specifically in glucose replenishment, hydration status, and mood elevation as compared to glucose drink. In summary, chocolate milk consumption able to remain the level of glucose in the blood, increase hydration level, decrease tiredness and fatigue, and increase vigour during the 2 hours recovery period after exercise. These findings are expected to help athletes and those involved in the process of energy recovery and hydration status after aerobic exercise, especially if an exercise is scheduled to be performed after the 2 hours of the recovery period, then the consumption of chocolate milk may improve the subsequent exercise performance. However, it is reasonable to suggest a further research on chocolate milk as a potential recovery drink especially on post-exercise lactate accumulation, delayed onset muscle soreness (DOMS), and post-exercise stress hormone level. These suggestions might provide deeper understanding on how chocolate milk enhances recovery and elevate mood after exercise. 
INTERNATIONAL JOURNAL OF ACADEMIC RESEARCH IN BUSINESS AND SOCIAL SCIENCES

Vol. 9, No. 6, June, 2019, E-ISSN: 2222-6990 @ 2019 HRMARS

\section{Acknowledgements}

The researcher would like to acknowledge the athletes from Universiti Pendidikan Sultan Idris for participating in this study. No financial contributions were received to fund the research.

\section{References}

Benton, D., \& Donohoe, R. T. (1999). The effects of nutrients on mood. Public health nutrition, 2(3a), 403-409.

Carlton, A., \& Orr, R. M. (2015). The effects of fluid loss on physical performance: A critical review. Journal of Sport and Health Science, 4(4), 357-363.

Cheuvront, S. N., Carter, R. I. I. I., \& Sawka, M. N. (2003). Fluid balance and endurance exercise performance. Current Sports Medicine Reports, 2(4), 202-208.

Cockburn, E., Hayes, P. R., French, D. N., Stevenson, E., \& St Clair Gibson, A. (2008). Acute milk-based protein-CHO supplementation attenuates exercise-induced muscle damage. Applied Physiology, Nutrition, and Metabolism, 33(4), 775-783.

Coyle, E. F. (2004). Fluid and fuel intake during exercise. Journal of Sports Sciences, 22(1), 39-55.

Enoka, R. M., \& Duchateau, J. (2008). Muscle fatigue: what, why and how it influences muscle function. The Journal of physiology, 586(1), 11-23.

Ferguson-Stegall, L., McCleave, E. L., Ding, Z., Doerner III, P. G., Wang, B., Liao, Y. H., Kammer, L., Liu, Y., Hwang, J., Dessard, B.M. and IVy, J.L. (2011). Postexercise carbohydrate-protein supplementation improves subsequent exercise performance and intracellular signaling for protein synthesis. The Journal of Strength \& Conditioning Research, 25(5),1210-1224.

Gandevia, S. C. (2001). Spinal and supraspinal factors in human muscle fatigue. Physiological Reviews, 81(4), 1725-1789.

Gilson, S. F., Saunders, M. J., Moran, C. W., Moore, R. W., Womack, C. J., \& Todd, M. K. (2010). Effects of chocolate milk consumption on markers of muscle recovery following soccer training: a randomized cross-over study. Journal of the International Society of Sports Nutrition, 7(1), 19.

Hartman, J. W., Tang, J. E., Wilkinson, S. B., Tarnopolsky, M. A., Lawrence, R. L., Fullerton, A. V., \& Phillips, S. M. (2007). Consumption of fat-free fluid milk after resistance exercise promotes greater lean mass accretion than does consumption of soy or carbohydrate in young, novice, male weightlifters. The American Journal of Clinical Nutrition, 86(2), 373-381.

Jentjens, R., \& Jeukendrup, A. E. (2003). Determinants of post-exercise glycogen synthesis during short-term recovery. Sports Medicine, 33(2), 117-144.

Karp, J. R., Johnston, J. D., Tecklenburg, S., Mickleborough, T. D., Fly, A. D., \& Stager, J. M. (2006). Chocolate milk as a post-exercise recovery aid. International Journal of Sport Nutrition and Exercise Metabolism, 16(1), 78-91.

Luden, N. D., Saunders, M. J., \& Todd, M. K. (2007). Postexercise carbohydrate-protein-antioxidant ingestion decreases plasma creatine kinase and muscle soreness. International Journal of Sport Nutrition and Exercise Metabolism, 17(1), 109-123.

Lunn, W. R., Pasiakos, S. M., Colletto, M. R., Karfonta, K. E., Carbone, J. W., Anderson, J. M., \& Rodriguez, N. R. (2012). Chocolate milk and endurance exercise recovery: protein balance, glycogen, and performance. Medicine and Science in Sports and Exercise, 44(4), 682-691. 
Pritchett, K., Bishop, P., Pritchett, R., Green, M., \& Katica, C. (2009). Acute effects of chocolate milk and a commercial recovery beverage on postexercise recovery indices and endurance cycling performance. Applied Physiology, Nutrition, and Metabolism, 34(6), 1017-1022.

Rao, T. S., Asha, M. R., Ramesh, B. N., \& Rao, K. J. (2008). Understanding nutrition, depression and mental illnesses. Indian Journal of Psychiatry, 50(2), 77.

Roy, B. D. (2008). Milk: the new sports drink? A Review. Journal of The International Society of Sports Nutrition, 5(1), 15.

Saunders, M. J., Kane, M. D., \& Todd, M. K. (2004). Effects of a carbohydrate-protein beverage on cycling endurance and muscle damage. Medicine \& Science in Sports \& Exercise, 36(7), 12331238.

Shirreffs, S. M., Armstrong, L. E., \& Cheuvront, S. N. (2004). Fluid and electrolyte needs for preparation and recovery from training and competition. Journal of Sports Sciences, 22(1), 57-63.

Shirreffs, S. M., Watson, P., \& Maughan, R. J. (2007). Milk as an effective post-exercise rehydration drink. British Journal of Nutrition, 98(1), 173-180.

Skillen, R. A., Testa, M., Applegate, E. A., Heiden, E. A., Fascetti, A. J., \& Casazza, G. A. (2008). Effects of an amino acid-carbohydrate drink on exercise performance after consecutive-day exercise bouts. International Journal of Sport Nutrition and Exercise Metabolism, 18(5), 473-492.

Spaccarotella, K. J., \& Andzel, W. D. (2011). Building a beverage for recovery from endurance activity: a review. The Journal of Strength \& Conditioning Research, 25(11), 3198-3204.

Terry, P. C., Lane, A. M., \& Fogarty, G. J. (2003). Construct validity of the Profile of Mood StatesAdolescents for use with adults. Psychology of Sport and Exercise, 4(2), 125-139.

Thomas, K., Morris, P., \& Stevenson, E. (2009). Improved endurance capacity following chocolate milk consumption compared with 2 commercially available sport drinks. Applied Physiology, Nutrition, and Metabolism, 34(1), 78-82.

Wurtman, R. J., \& Wurtman, J. J. (1995). Brain serotonin, carbohydrate-craving, obesity and depression. Obesity Research, 3(S4), 477S-480S.

Valentine, R. J., Saunders, M. J., Todd, M. K., \& St. Laurent, T. G. (2008). Influence of carbohydrateprotein beverage on cycling endurance and indices of muscle disruption. International Journal of Sport Nutrition and Exercise Metabolism, 18(4), 363-378.

\section{Corresponding Author Email}

aijratul@fsskj.upsi.edu.my 